\title{
REKONSTRUKSI SISTEM PEMUNGUTAN PAJAK PENGHASILAN (PPh) BADAN BERBASIS NILAI KEADILAN
}

\author{
Amin Purnawan \\ Fakultas Hukum Universitas Islam Sultan Agung (Unissula) Semarang \\ E-mail: aminpurna@yahoo.com
}

\begin{abstract}
Fairness in taxation policy can be viewed from: first, the equilibrium relationship between tax authorities and taxpayers, secondly, equitable allocation of the tax burden on various segments of society according to his ability. Corporate income tax collection system did not reflect the sense of justice because the application of the single rate system of corporation tax burden caused injustice, and the authority of the tax authorities are still too broad. It needs political reconstruction based corporate income tax law of justice based on Pancasila, through structuring and strengthening aspects of philosophy, the subtance and structure of tax law. Progressive tax law by using a new paradigm is expected to display the figure of taxation more equitable and humane, so as to promote awareness of voluntary compliance from tax payer, followed by transparency and responsibility of countries to achieve people's welfare.
\end{abstract}

Keywords: Reconstruction, Corporate Income Taxes, Juctice

\begin{abstract}
Abstrak
Keadilan dalam sistem pemungutan pajak dapat dilihat dari: pertama, keseimbangan hubungan antara fiskus dan wajib pajak; kedua, pemerataan alokasi beban pajak terhadap segenap lapisan masyarakat berdasarkan kemampuannya. Sistem pemungutan pajak penghasilan (PPh) badan belum mencerminkan rasa keadilan karena penerapan sistem tarif tunggal menimbulkan ketidakadilan beban pajak korporasi, dan wewenang (otoritas) fiskus masih terlalu luas. Maka diperlukan rekonstruksi politik hukum pajak penghasilan badan berbasis keadilan berdasarkan Pancasila, melalui penataan dan penguatan aspek filosofi, substansi dan struktur hukum pajak. Hukum pajak yang progresif dengan menggunakan paradigma baru diharapkan akan menampilkan sosok perpajakan yang lebih adil dan humanis, sehingga dapat mendorong munculnya kepatuhan sukarela dari wajib pajak yang diikuti dengan transparansi dan tanggung jawab negara untuk mewujudkan kesejahteraan rakyat.
\end{abstract}

Kata Kunci: Rekonstruksi, Pajak Penghasilan, Keadilan

\section{Pendahuluan}

Hubungan antara korporasi, pajak dan negara menarik untuk dikaji melalui optik pajak penghasilan badan, karena merupakan salah satu cara di mana negara secara langsung campur tangan dalam urusan perusahaan. Ketika pajak perusahaan pertama kali diadopsi, "sebenarnya" terdapat pandangan dominan bahwa pajak terutama digunakan sebagai alat mengatur manajemen perusahaan dalam kaitannya dengan stakeholders lainnya serta negara. ${ }^{1}$

Reuven Avi-Yonah, 2004, Corporations, Society, and The State: A Defence of The Corporate Tax, University
Pengenaan pajak pada dasarnya adalah pemaksaan negara terhadap unit-unit ekonomi untuk mengurangi pendapatan mereka dengan cara membayar pajak. Hasil pembayaran pajak oleh unit ekonomi individual dan korporasi merupakan penerimaan bagi negara dalam Anggaran Pendapatan dan Belanja Negara (APBN). Penerimaan tersebut digunakan untuk membiayai ketersediaan barang dan jasa publik (public goods and public services) yang tidak

Of Michigan: John M. Olin Center For Law and Economics, hlm. 1 
dapat dipenuhi oleh masyarakat secara terpisah (private goods).

Pajak merupakan salah satu sumber pendapatan yang sangat penting bagi suatu negara. Pajak tidak hanya berfungsi sebagai sumber dana pemerintah, tetapi juga alat untuk mengatur perekonomian dan kese-jahteraan rakyat. Kebijakan perpajakan yang efektif dapat berperan untuk menjaga keseimbangan ekonomi dan inflasi. ${ }^{2}$

Pemerintah saat ini dalam posisi dilematis, di satu sisi ingin mengurangi ketergantungan terhadap utang luar negeri dalam menutup defisit, dan karena itu peningkatan pajak adalah salah satu solusi. Tetapi di sisi lain, dunia usaha yang terlampau tertekan akan menyebabkan kelesuan investasi, yang ujungnya adalah pengangguran yang meningkat.

Sejak diberlakukannya reformasi di bidang perpajakan, penerimaan negara dari sektor pajak terus meningkat. Dilihat dari pendapatan negara dan hibah dalam APBN tahun 2007 sebesar 690 triliun rupiah, penerimaan pajak menyumbang sebesar 492 triliun (71.30\%). Tahun 2008 total pendapatan negara sebesar 759,3 triliun dan penerimaan pajak sebesar 583,7 triliun rupiah $(76,87 \%)$. Penerimaan Pajak Penghasilan di tahun 2008 memberikan kontribusi sebesar $41 \%$ terhadap penerimaan dalam negeri. Bila dibandingkan sejak awal diberlakukannya reformasi perpajakan tahun 1983, maka realisasi penerimaan PPh meningkat dari 2,121 Triliun di tahun 1983 menjadi 327,49 Triliun pada tahun 2008 (atau $15.440 \%) .^{3}$

Maksud dan tujuan perlunya dilakukan rekonstruksi sistem pemungutan pajak penghasilan badan berbasis nilai keadilan, karena peran strategis pemungutan pajak penghasilan badan dalam pembangunan dan penerimaan negara. ${ }^{4}$ Seringkali sistem pemungutan pajak mengalami distorsi atau penyimpangan terhadap cita hu-

Nordin, "Pajak Daerah Sebagai Sumber Pendapatan Daerah/Kota Di Era Otonomi Daerah", Jurnal Delegasi 2 Agustus 2005, STIA Banjarmasin, hlm. 110

Nota Keuangan dan RAPBN 2008.

4 Lihat Hadion Wijoyo, "Peranan Hukum Pajak Dalam Pembangunan Ekonomi", Jurnal Hukum Respublica, Vol. 4 (2) Tahun 2005, Universitas Lancang Kuning Pekanbaru, hlm. 237-253 kum sehingga tidak dihasilkan hukum yang mencerminkan cita hukum. Dengan ditemukannya realitas sosial berupa ketidakadilan, dan dampaknya, selanjutnya akan dijadikan dasar kajian dalam membangun kembali (rekonstruksi) sistem pemungutan pajak penghasilan bagi wajib pajak badan yang berbasis nilai keadilan ber-dasarkan Pancasila.

Paparan di atas memperlihatkan bahwa kontribusi PPh sangat signifikan, namun dapat menimbulkan beban yang terlalu berat bagi korporasi jika tidak dipungut secara adil. Mencermati hal tersebut, maka tulisan ini di maksudkan untuk menjelaskan tentang arti penting pembangunan sistem pemungutan pajak penghasilan (PPh) badan berbasis keadilan, dan politik hukum pajak yang adil bagi korporasi.

\section{Pembahasan}

Sistem Pemungutan Pajak Penghasilan (Pph) Badan Belum Mencerminkan Keadilan

Pemungutan pajak oleh aparat perpajakan membawa beberapa implikasi. Pertama, berkaitan dengan ketentuan tentang tarif atau besaran pajak, karena tarif adalah variabel yang memberikan pengaruh pada kesejahteraan para Wajib Pajak (WP) dalam bentuk pengurangan terhadap aliran penghasilan yang digunakan untuk membentuk aset dalam aktivitas ekonomi para WP.

Undang-undang Pajak Penghasilan (PPh) mengatur besaran tarif pajak pada Pasal 17. Perubahan yang paling menarik adalah perubahan tarif pajak bagi WP Badan dan Bentuk Usaha Tetap (BUT). Di dalam UU No. 36 Tahun 2008 Pasal 17 ayat 1 (b), tarif bagi WP Badan dan BUT ditetapkan sebagai tarif tunggal (flat rate) yaitu sebesar $28 \%$. Tarif ini mulai tahun 2010 diturunkan lagi menjadi 25\%. Perubahan dari semula tarif progresif menjadi tarif tunggal boleh jadi merupakan jawaban atas banyak usulan dari para pelaku usaha, agar tarif pajak di Indonesia lebih sederhana dan dapat mendorong dunia usaha (korporasi) untuk semakin kompetitif, baik dengan kekuatan internal mau pun dengan adanya investasi-investasi dari luar negeri. 
Selain perubahan tarif progresif menjadi tarif tunggal, perubahan berikutnya yang di nikmati oleh WP Badan khususnya WP Badan dalam negeri berbentuk Perseroan Terbatas Terbuka (Tbk.) adalah hak untuk menikmati tarif khusus yaitu $5 \%$ lebih rendah dibanding tarif tunggal yang sudah ditetapkan sebesar 28\% (untuk tahun pajak 2009) dan 25\% (mulai tahun pajak 2010). Namun untuk menikmati hak ini, WP Badan dalam negeri tersebut mempunyai kewajiban memperdagangkan di bursa efek di Indonesia paling sedikit $40 \%$ dari jumlah saham yang disetor dan kewajiban untuk memenuhi persyaratan tertentu lainnya (Pasal 17 ayat 2b).

Untuk mengetahui lebih lanjut tentang implikasi perubahan tarif tersebut terhadap aliran penghasilan WP Badan dan BUT, di bawah ini disajikan ilustrasi perhitungan pajak $\mathrm{PPH}$ Badan. Ilustrasi penghitungan beban PPh badan di atas menunjukkan adanya beban pembayar- an pajak yang meningkat dengan penetapan sistem tarif yang baru. Kebijakan penetapan tarif pajak penghasilan yang baru justeru memberatkan sebagian besar WP perusahaan, dan hanya sedikit memberikan keuntungan bagi WP perusahaan khususnya yang memiliki Penghasilan Kena Pajak (PKP) besar. Dengan kata lain, tarif pajak yang baru mengakibatkan terjadinya ketidakadilan dalam penetapan beban dengan teknik komparatif pada berbagai level penghasilan. Dari ilustrasi tersebut, kita dapat menilai apakah perubahan tarif yang sudah termaktub di dalam UU perubahan memberikan benefit ekonomi kepada WP atau sebaliknya. Tarif Pajak yang diterapkan terhadap Penghasilan Kena Pajak Wajib Pajak Badan untuk tahun 2008 adalah Tarif Pajak Progresif sedangkan untuk tahun 2009 adalah Tarif Pajak Tunggal, berikut adalah tabel perbandingan tarif pajak penghasilan badan.

Tabel 1. Perbandingan Tarif PPh Badan

\begin{tabular}{|l|c|l|}
\hline \multicolumn{1}{|c|}{ Lapisan Kena Pajak } & UU No.17/2000 & \multicolumn{1}{c|}{ UU No.36/2008 } \\
\cline { 1 - 2 } Sampai dengan Rp. 50.000.000,- & $10 \%$ & Tarif tunggal \\
\cline { 1 - 2 } Di atas Rp.50.000.000 s/d 100.000.000,- & $15 \%$ & 25\% (mulai tahun 2009) \\
\cline { 1 - 2 } Di atas Rp. 100.000.000,- & $30 \%$ & \\
\hline
\end{tabular}

Tabel 2. Ilustrasi Penghitungan PPh Badan

\begin{tabular}{|c|l|l|c|c|}
\hline Tahun & Penghasilan Kena Pajak & Dasar Penghitungan & Tarif PPh & $\begin{array}{c}\text { Pajak } \\
\text { Penghasilan }\end{array}$ \\
\hline 2008 & $\mathrm{Rp} \mathrm{50.000.000,-}$ & $\mathrm{Rp} 50.000 .000,-$ & $10 \%$ & $\mathrm{Rp} \mathrm{5.000.000,-}$ \\
\hline 2009 & $\mathrm{Rp} \mathrm{50.000.000,-}$ & $\mathrm{Rp} 50.000 .000,-$ & $28 \%$ & $\mathrm{Rp} 14.000 .000,-$ \\
\hline
\end{tabular}

\begin{tabular}{|c|c|c|c|c|}
\hline Tahun & Penghasilan Kena Pajak & Dasar Penghitungan & Tarif PPh & Pajak Penghasilan \\
\hline \multirow[t]{2}{*}{2008} & Rp 100.000.000,- & Rp $\quad 50.000 .000,-$ & $10 \%$ & Rp 5.000.000,- \\
\hline & & $\begin{array}{ll}\text { Rp } & 50.000 .000,-\end{array}$ & $15 \%$ & Rp 7.500.000,- \\
\hline \multicolumn{3}{|r|}{ Total } & Rp12.500.000,- & \\
\hline 2009 & Rp 100.000.000,- & Rp 100.000.000,- & $28 \%$ & Rp28.000.000,-- \\
\hline
\end{tabular}

\begin{tabular}{|c|c|c|c|c|}
\hline Tahun & 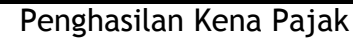 & Dasar Penghitungan & Tarif PPh & Pajak Penghasilan \\
\hline 2008 & Rp 150.000.000,- & $50.000 .000,-$ & $10 \%$ & Rp 5.000.000,- \\
\hline & & $50.000 .000,-$ & $15 \%$ & Rp 7.500.000,- \\
\hline & & $50.000 .000,-$ & $30 \%$ & Rp15.000.000,- \\
\hline \multicolumn{4}{|r|}{ Total } & Rp27.500.000,-- \\
\hline 2009 & Rp 150.000.000,- & $\begin{array}{ll}\mathrm{Rp} & 150.000 .000,-\end{array}$ & $28 \%$ & Rp42.000.000,- \\
\hline
\end{tabular}


Terdapat benturan antara asas kesederhanaan pemungutan pajak (simplicity) dengan asas keadilan (justice). Tuntutan akan sistem pemu-ngutan pajak penghasilan badan yang sederhana, misalnya dengan menggunakan tarif tunggal, ternyata berbenturan dengan realitas adanya jumlah penghasilan yang tidak sama, hal mana akan lebih memberikan rasa keadilan apabila menggunakan tarif progresif dengan menggunakan lapisan tarif.

Kedua, aparatur perpajakan dalam setting peraturan perundang-undangan perpajakan Indonesia diberikan otoritas (kewenangan) yang sangat besar sehingga melahirkan konstruksi keterhubungan yang sub-ordinatif. Dalam istilah yang lebih ekstrim hubungan antara fiskus dan WP tanpa mekanisme checks and balances. Dari kacamata aparatur perpajakan, pemberian otoritas posisi superior ini dapat dibenarkan, oleh karena konstruksi keterhubungan yang terbangun adalah antara warga negara dan negara. Namun demikian, pandangan yang demikian tidaklah dapat dibenarkan. Reduksi posisi negara melalui representasi aparatur perpajakan justru berpotensi negatif dan kontra produktif. Kesalahan personal aparatur perpajakan berpotensi dapat dibenarkan oleh karena diangkat pada level tindakan negara. ${ }^{5}$

Menguatnya otoritas aparatur perpajakan tersebut memiliki keterkaitan yang erat dengan maraknya kejahatan dalam bidang per-pajakan. Dua hal tersebut memiliki keterkaitan yang erat satu dengan yang lainnya, oleh karena semakin besar otoritas kewenangan yang dimilki oleh seseorang akan semakin besar peluang terbuka untuk melakukan kejahatan.

Perubahan cara pandang tentang pajak dapat dilihat dengan membandingkan pandangan dari para ahli, yaitu Jean Bodin (1530-1596), Thomas Hobbes (1588-1679), dan Adam Smith (1723-1790). Bodin, pemikir awal tentang kedaulatan negara, berpendapat bahwa negara berdaulat seharusnya memperoleh pendapatan dari kekayaan yang dimilikinya. Thomas Hobbes mulai mengubah cara berpikir dengan menya-

Tri Budiyono, "Pemusatan Otoritas Aparatur Perpajakan dan Kejahatan Pajak", Jurnal Hukum Vol. XV (3) Desember 2003, FH Unissula Semarang, hlm. 546. takan bahwa pajak adalah sumber penerimaan utama negara. Tapi Adam Smith sangat ragu tentang kepemilikan negara, dalam pandangannya, pajak seharusnya menjadi sumber utama penerimaan negara. Menurutnya, hukum pajak menyediakan instrumen khusus bagi negara agar dapat memaksa warga negaranya untuk membayar pajak, namun demikian sifat pemaksaan pajak harus dibagi secara adil sebagai beban pajak.

Adam Smith dalam bukunya "Wealth of Nations", mengemukakan empat asas pemungutan pajak ("The Four Cannons Maxims Taxation"), supaya peraturan pajak adil harus memenuhi syarat: asas kesamaan (equality) dan keadilan (equity), asas kepastian hukum (certainty), asas tepat waktu (convenient of payment) dan asas economic of collection dimana biaya pemungutan pajak harus relatif kecil dibandingkan dengan pajak yang masuk. Berdasarkan keempat asas tersebut, asas kesamaan (equality) dan keadilan (equity) yang sangat relevan dengan penulisan ini.

Suatu kebijakan perpajakan dikatakan adil apabila terdapat keseimbangan hak dan kewajiban antara wajib pajak dengan fiskus. Asas-asas pemungutan pajak di atas menjadi pedoman bagi pembuat undang-undang perpajakan agar undang-undang tersebut dapat mencerminkan rasa keadilan. Asas-asas tersebut dijadikan sebagai ukuran untuk menguji apakah suatu undang-undang perpajakan telah mencerminkan rasa keadilan atau tidak, sedangkan kriterianya terletak pada sejauhmana asas-asas atau syarat-syarat pemungutan pajak tersebut diintrodusir dalam undang-undang yang bersangkutan.

Suatu hukum atau peraturan perundangundangan yang baik adalah adil, berkaitan dengan hal ini peraturan yang mendasari pemungutan pajak hendaknya harus sesuai dengan syarat-syarat keadilan. Keadilan dalam kebijakan perpajakan dapat dilihat dari: keadilan dalam hubungan antara pemerintah dan wajib pajak, dan keadilan dari alokasi beban pajak pada berbagai golongan masyarakat.

Persoalannya adalah bentuk keadilan yang bagaimana yang bisa diterapkan dalam 
sistem pemungutan pajak penghasilan ( $P P h)$ badan. Hal ini karena di dalam pemberian kewenangan kepada negara untuk memungut pajak berhadapan dua kepentingan, yakni kepentingan penerimaan kas negara dihadapkan pada keber-langsungan korporasi. Karena itu, setiap materi peraturan perundang-undangan tentang pemungutan pajak harus mencerminkan keadilan beban pajak yang merata bagi setiap warga negara sesuai kemampuannya, serta adanya keseimbangan hak dan kewajiban antara fiskus dengan WP.

Apabila ditelusuri makna nilai keadilan sosial bersama nilai-nilai dasar Pancasila lainnya, maka nilai keadilan sosial merupakan salah satu nilai yang dijadikan tujuan dari sebuah sistem nilai. Bagi bangsa Indonesia, nilai-nilai Pancasila bahkan ditempatkan sebagai paradigma politik hukum. ${ }^{6}$ Pancasila memiliki nilainilai dasar yang bersifat universal dan tetap. Nilai-nilai itu tersusun secara hierarkis dan piramidal. Substansi nilai-nilai dasar Pancasila yang terdiri atas nilai ketuhanan, kemanusiaan, persatuan, kerakyatan, dan keadilan sosial merupakan suatu sistem nilai. $^{7}$

\section{Politik Hukum Perpajakan dalam Pembangun- an Sistem Hukum Nasional}

Pada prinsipnya politik adalah aktivitas dalam memilih suatu tujuan tertentu. Oleh karena itu dalam hukum akan berhadapan dengan persoalan yang sama, yaitu keharusan untuk menentukan suatu pilihan mengenai tujuan maupun cara-cara yang hendak dipakai untuk mencapai tujuan tersebut. Kesemuanya itu masuk ke dalam bidang studi politik hukum. ${ }^{8}$

Eddy Asnawi, "Relevansi Politik Hukum dan Strategi Pembangunan Hukum dalam Rangka Menuju Sistem Hukum Nasional", Jurnal Respublica Vol. 3 No. 1 Tahun 2003, Universitas Lancang Kuning Pekanbaru, hlm.95; Lihat C.F.G. Sunaryati Hartono, "Politik Hukum Bhineka Tunggal Ika Dalam Pembangunan Hukum Nasional", Majalah Hukum Nasional Vol. 8 No. 2 Tahun 2008 BPHN, hlm. 39-50

7 Lihat Astim Riyanto, "Pancasila Dasar Negara Indonesia”, Jurnal Hukum dan Pembangunan Vol. 37 No. 3 Juli-September 2007, FH UI Jakarta, hlm. 457-492

8 Hernalia Ratna, “Implementasi Politik Hukum Dalam Amandemen UUD 1945 Terhadap Pembangunan Hukum Sistem Hukum Nasional”, Jurnal Perspektif Hukum Vol. 6 No. 2 November 2006, Universitas Hang Tuah Surabaya, hlm. 106
Politik hukum nasional di bidang perpajakan tercantum dalam Pasal 23A UUD Negara Republik Indonesia tahun 1945, yang menentukan bahwa, "pajak dan pungutan lain yang bersifat memaksa untuk keperluan Negara diatur dengan Undang-Undang”. Artinya, pungutan pajak oleh pemerintah dalam menyelenggarakan fungsi pajak untuk menopang pemasukan pajak ke kas negara dan juga menunjang peningkatan pertumbuhan ekonomi dan sosial, harus mendapat persetujuan rakyat melalui wakilwakilnya yang duduk di DPR.

Adapun caranya, pemerintah dapat melakukan antara lain melalui ekstensifikasi dan intensifikasi pajak. Hal ini berkaitan dengan perlunya meningkatkan jumlah wajib pajak (tax payers), karena kenyataannya tax ratio kita masih sangat rendah (tidak mencapai $13 \%$ Produk Domestik Bruto). Dengan menjaring wajib pajak baru, menurunkan tarif pajak dan tax amnesty, diharapkan dapat mendorong percepatan pemulihan ekonomi serta jumlah pemasukan pajak yang signifikan dan dapat digunakan untuk meningkatkan kesejahteraan rakyat.

Politik pembangunan hukum nasional di bidang perpajakan, dalam rangka mengubah hukum pajak (peraturan perundang-undangan) harus sejalan dengan dasar dan arah politik. Negara, dengan demikian melalui pemerintah bersama DPR bila akan mengubah hukum di bidang perpajakan tentunya tetap pada koridor kepastian dan keadilan hukum dengan tujuan menegakkan supremasi hukum. Untuk itu, pembentukan hukum pajak harus memperhatikan asas dan kaidah-kaidah hukun yang tepat dan benar termasuk pelaksanaannya. Mengingat ada beberapa hukum yang dibentuk memiliki sifat yang serupa hukum kolonial, kalau tidak isi kaidah, rumusan kaidah, bahkan penerapannya yang bersifat kolonialistik (seperti UU Ketentuan Umum dan Tata Cara Perpajakan dan UU Pajak Penghasilan yang berkaitan dengan sistem memungut pajak).

Urgensi Rekonstruksi Sistem Pemungutan Pajak Penghasilan Badan Berbasis Keadilan 
Tidak dapat dipungkiri kenyataan bahwa pajak adalah basis material dan darah kehidupan (lifeblood) negara dan kekuasaannya. Tidak ada negara otoriter maupun demokratis yang dapat bertahan hidup dan menjalankan roda kekuasaannya tanpa pajak rakyat. Pajak dibayar, negara tegak; pajak diboikot, negara runtuh. Jika diteorikan bahwa negara merupakan hasil kontrak sosial, maka sesungguhnya dalam "berpajak"lah kontrak itu diberi isi dari hari ke hari. Oleh sebab itu, visi dan bentuk negara akan sangat ditentukan oleh bagaimana basis material negara yang bernama "pajak" itu diberi makna. Konsep yang diberikan masyarakat terhadap pajaknya, akan sangat menentukan konsep negara yang dibangunnya. ${ }^{9}$

Pajak merupakan hal penting dalam urusan bernegara, sebab dengan pajak itulah distribusi keadilan sosial dapat dilakukan. Negara melalui instrumen pajak akan dapat mengurangi tingkat kecemburuan sosial warga negara yang tidak memiliki sumber-sumber ekonomi yang memadai. Indonesia sebagai negara hukum, maka yang dipakai sebagai dasar alasan pembenar memungut pajak adalah hukum. Hal ini dapat diketemukan dalam Pasal 23 A UUD 1945 yang menentukan Pajak dan pungutan lain yang bersifat memaksa untuk keperluan negara diatur dengan undang-undang.

Kebijakan perpajakan yang dibuat pemerintah haruslah berlandaskan pada wewenang dari lembaga perwakilan rakyat kepada pemerintah, dengan tujuan untuk menghindari tindakan sewenang-wenang pemerintah selaku penguasa. Selain dari itu juga bertujuan untuk mencapai suatu iklim perpajakan yang adil dan kondusif. Kebijakan perpajakan tersebut merupakan kelanjutan dari kebijakan perpajakan sebelumnya dengan modifikasi tertentu, yaitu (1) penyederhanaan UU perpajakan; (2) penyederhanaan sistem administrasi perpajakan; (3) pemberian kepercayaan wajib pajak untuk menghitung, memperhitungkan, dan membayar sendiri pajak terutang. Pelaksanaan pemungut-

9 Lihat Edi Sunarko, “Kebijakan Perpajakan Pemerintah Republik Indonesia Terhadap Kegiatan Investasi Dalam Kerangka Asean Free Trade Area (AFTA)", Jurnal Hukum dan Dinamika Masyarakat, Oktober 2004, FH Untag Semarang, hlm. 69-86 an pajak tentunya jangan sampai menimbulkan hambatan atau perlawanan masyarakat sehingga seharusnya dipenuhi syarat-syarat pemungutan pajak yang baik yaitu antara lain: adil, kepastian hukum, ekonomis, efisien dan sederhana.

Beberapa aspek yang perlu dipertimbangkan antara lain adalah Pertama, keadilan beban pajak (tax base) antara WP Badan dan WP Orang Pribadi berkaitan dengan besaran tarif (tax rate); kedua, sistem pemungutan pajak antara pajak datar (flat rate) dan pajak progresif; ketiga, kecenderungan pajak internasional; keempat, daya saing investasi (business frien$d(y)$.

Modernisasi perpajakan yang dilakukan pemerintah tentunya tidak hanya untuk mengejar optimalisasi pemungutan pajak (budgeter) semata. Masih ada sisi lain yang juga penting dilakukan secara bersama-sama untuk menuju adanya perubahan paradigma perpajakan (change of tax paradigm). Ketentuan, prosedur, dan aktivitas perpajakan juga terus diarahkan untuk peningkatan pelayanan agar menjadi business friendly bagi masyarakat terutama para pelaku bisnis.

Kondisi hukum ekonomi Indonesia juga perlu disiapkan dalam rangka memenuhi kebutuhan-kebutuhan hukum di era global. Harmonisasi melalui kebijaksanaan fiskal yang menjurus pada keseragaman dibidang infrastruktur hukum akan berdampak pada kenyamanan untuk berinvestasi dari pelaku usaha negara maju di negara berkembang.

Melihat tingkat kepatuhan wajib pajak khususnya perusahaan sebagai pembayar PPh badan yang cukup tinggi bila dibandingkan PPh pribadi, maka formula hukum yang tepat adalah membuat PPh badan tetap terjaga (intensifikasi). Sementara itu, PPh pribadi perlu diperluas jangkauannya (ekstensifikasi).

Kepatuhan pajak merupakan kunci pelaksanaan atas kewajiban untuk menyetor dan melaporkan pajak yang terutang sesuai dengan ketentuan perpajakan. Kepatuhan yang diharapan adalah kepatuhan sukarela bukan kepatuhan terpaksa. Untuk itu diperlukan keadilan dan keterbukaan dalam menerapkan peraturan 
perpajakan dan pelayanan yang prima terhadap wajib pajak serta pemanfaatan penerimaan pajak untuk kesejah-teraan rakyat.

Setiap transaksi bisnis dunia usaha menimbulkan potensi pajak, baik pajak pusat, pajak daerah, cukai dan retribusi daerah yang menjadi beban yang harus dipikulnya sendiri. Bila perusahaan, pengusaha, profesional mengabaikan aspek hukum pajak tersebut, maka pada saat tertentu akan menimbulkan kerugiannya sendiri dengan jumlah yang tidak bisa terduga dan menjadi kendala usaha di masa yang akan datang. Perlu kepedulian dari wajib pajak untuk memperhitungkan aspek pajak yang harus dipikul dalam setiap transaksi bisnis yang dilakukan setiap saat, sehingga dalam memenuhi kewajibannya tetap dalam koridor hukum dan kelangsungan usaha tetap stabil.

Mencermati hal di atas, maka pajak memiliki tiga tujuan pokok. Pertama, sebagai sumber penerimaan negara; kedua, alat untuk distribusi pendapatan; dan ketiga, mendorong pertumbuhan ekonomi. Usaha mencapai target penerimaan pajak tersebut harus dilakukan dengan memperhatikan tujuan ketiga yaitu mendorong pertumbuhan ekonomi melalui penciptaan iklim investasi yang kondusif. Tanpa memperhatikan dampaknya terhadap iklim investasi dan pertumbuhan ekonomi, maka pajak akan dirasakan sebagai beban berat bagi masyarakat, apalagi jika tidak didukung dengan kebijakan belanja fiskal yang manfaatnya dapat dirasakan oleh masyarakat.

Platform pajak yang ideal bertujuan untuk menciptakan sistem perpajakan yang adil, jelas dan setara bagi semua pembayar pajak. Secara keseluruhan, keadilan pajak terlihat untuk membatasi jumlah peraturan pajak dan peraturan yang menguntungkan satu segmen dari populasi pajak membayar lebih dari yang lain. Pajak yang ideal menurut Sandiaga S. Uno adalah jika pajak tidak mengganggu aktivitas ekonomi, sehingga perlu dilakukan perluasan basis pembayar pajak serta penurunan tarif pajak untuk meningkatkan kepatuhan wajib pajak. ${ }^{10}$

10 Sandiaga S. Uno, Ketua Bidang UMKM Kadin dan anggota Komite Ekonomi Nasional, dalam Seminar Bisnis tentang "Insentif Pajak dalam Mendorong Dunia Bisnis",
Pembaruan perpajakan dilakukan secara menyeluruh pada 1984 , di mana pemerintah menetapkan sistem perpajakan yang menopang pemba-ngunan dengan mengeluarkan undangundang tentang Ketentuan Umum dan Tata Cara Perpajakan, UU Pajak Penghasilan, dan UU Pajak Pertam-bahan Nilai. Di samping itu, pemerintah menerapkan kebijakan perpajakan dengan menerapkan asas keadilan, artinya yang memiliki kemampuan memang harus membayar, dan yang berkemampuan lebih besar harus membayar pajak lebih besar.

Telah lahir beberapa undang-undang perpajakan yang baru dalam pembaharuan sistem perpajakan nasional (tax reform), yaitu antara lain: UU No. 6 tahun 1983 sebagaimana telah diubah dengan UU No. 9 tahun 1994 dan UU No. 16 Tahun 2000 tentang Ketentuan Umum dan Tata Cara Perpajakan sebagaimana telah di ubah dengan UU No. 28 Tahun 2007 serta UU No. 16 Tahun 2009; UU No. 7 tahun 1983 sebagaimana telah diubah dengan UU No. 7 tahun 1991, UU No. 10 tahun 1994 dan UU No. 17 tahun 2000 serta UU No. 36 Tahun 2008 tentang Pajak Penghasilan; UU No. 8 tahun 1983 sebagaimana yang telah diubah dengan UU No. 11 tahun 1994 dan UU No. 18 tahun 2000, serta UU No. 42 tahun 2009 tentang Pajak Pertambahan Nilai Barang dan Jasa dan Pajak Penjualan atas Barang Mewah.

Melalui reformasi dan modernisasi perpajakan, diharapkan mampu menciptakan kesetaraan antara Wajib Pajak (WP) dengan fiskus. Selama ini terjadi pemusatan kewenangan pada Direktorat Jenderal Pajak (DJP), ini akan mempersulit kontrol dan membuka peluang kompromi serta penyalahgunaan kekuasaan. Sebaiknya, aparat DJP cukup sebagai pemungut pajak, lalu ada lembaga lain yang berperan sebagai regulator dan lembaga lain lagi sebagai pengawas independen atau bisa pula dibentuk ombudsman perpajakan.

Mengenai masalah kesetaraan, kenyataan menunjukkan bahwa dalam sistem perpajakan manapun di dunia, termasuk di Indonesia sejak lama, petugas pajak diberikan kewenangan

diselenggarakan oleh Kanwil Pajak Jateng II dan Tax Center USB, Solo, 7 Juli 2010. 
(power) yang besar sesuai UU untuk memungut pajak dari masyarakat. Kendati demikian, tidak berarti power dari otoritas pajak tersebut tidak terbatas. Sebagaimana kita ketahui bersama bahwa power dari otoritas perpajakan yang "berlebihan" menjadi sumber penyalahgunaan, dan ketidak-pastian dalam penerapan UU Perpajakan. Masyarakat dapat menilai pemberian power yang lebih besar dalam UU Perpajakan kepada petugas pajak dalam proses pemeriksaan, proses keberatan, dan proses peradilan serta kekuatan untuk melakukan penyegelan dan pemblokiran rekening berdasarkan dugaan subjektif petugas kurang memperhatikan kesulitan-kesulitan para pembayar pajak dan kondisi ekonomi warga masyarakat yang begitu sulit untuk sekarang ini.

Prinsip kesetaraan, dengan demikian, harus diartikan secara luas sebagai keseimbangan antara kewajiban dan hak dari pembayar pajak, dan tidak diartikan secara sempit sebatas pemberian sanksi yang seimbang kepada wajib pajak dan petugas pajak yang melanggar UU Perpajakan. Hal ini terlihat dimana kewajiban membayar pajak dan ketetapan pajak yang di bebankan kepada masyarakat belum diimbangi dengan kemudahan-kemudahan dalam proses memperoleh restitusi kelebihan pembayaran pajak dan penyelesaian proses pemeriksaan.

Semangat dari reformasi perpajakan adalah untuk meminimalkan pertemuan antara aparat pajak dan wajib pajak. Diharapkan pembayaran pajak bisa berjalan lebih cepat dan aman sehingga terhindar dari SPT palsu serta dapat mengurangi terjadinya kolusi antara WP dan fiskus. Hal tersebut tidak akan berhasil, tanpa adanya moral dan etika yang baik dari kedua belah pihak.

Selain itu, reformasi perpajakan harus mampu memberikan kegairahan dunia usaha. Karena berkembangnya dunia usaha, maka penerimaan pajak akan semakin besar pula. Kebijakan perpajakan sangat berpengaruh terhadap investasi yang masuk. Sebab menurut kalangan pelaku bisnis, pajak merupakan kendala investasi terbesar, di samping masalah keama- nan, hukum, perburuhan, otonomi daerah dan penyelundupan. ${ }^{11}$

Pemasukan pajak yang besar, dengan cara membebani sektor riil/investasi dapat mengakibatkan melemahnya investasi, dan berkurangnya daya beli serta kemampuan masyarakat, yang berakibat berkurangnya pemasukan pajak. Berkurangnya perolehan pajak berarti melemahnya kemampuan negara untuk menyejahterakan rakyat.

Menurut Bank Dunia (World Bank), reformasi perpajakan di negara berkembang dapat merupakan suatu komponen dari reformasi fiskal sebagai penyesuaian struktural (structural adjusment) untuk mengurangi distorsi insentif ekonomi dan akibat dari ketidak-efisienan dan ketidakadilan alokasi sumber daya. Walaupun pola perpajakan antar negara dapat berbeda (karena faktor ekonomi, sosial, budaya, dan histori), namun pada umumnya suatu sistem perpajakan (tax system) yang kurang baik didesain atau difungsikan secara kurang tepat dapat menimbulkan berbagai masalah, seperti ketidakcukupan penerimaan, distorsi yang mengurangi kesejahteraan dan pertumbuhan ekonomi, ketidakadilan dalam pemerataan beban pajak baik horizontal maupun vertikal dan kompleksitas administrasi.

Sehubungan dengan beberapa masalah tersebut, Lesson mengemukakan bahwa pembaruan perpajakan pada umumnya diarahkan untuk dapat mencapai beberapa sasaran, seperti menghasilkan penerimaan dalam jumlah yang cukup, stabil, fleksibel, dan berkelanjutan, mengurangi beban inefisiensi dan excess burden dari perpajakan atau meningkatkan efisiensi ekonomi (optimalisasi alokasi sumber daya dan mendukung pertumbuhan ekonomi), memperingan beban kelompok kurang mampu dan mendesain struktur pajak menjadi lebih adil baik secara horizontal maupun vertikal dan

\footnotetext{
11 Bandingkan dengan Andrinato Dwi Nugroho, “Anti Avoidance Rules di Indonesia Pasca amandemen UU Pajak Penghasilan", Jurnal Mimbar Hukum Vol. 21 No. 1 Februari 2009, FH UGM Yoygakarta, hlm. 109-126
} 
memperkuat administrasi perpajakan dan minimalisasi biaya administrasi dan kepatuhan. ${ }^{12}$

Pengelolaan pajak di negara kita dalam dua dekade ini, berkembang sangat dinamis. Ini terlihat dari perkembangan yang dimulai sejak dilakukannya reformasi perpajakan (tax reform) pada tahun 1983. Melalui perubahan seperti organisasi, sistem, sarana dan prasarana kerja, peraturan maupun aparat yang mengelola pajak, telah memberikan kontribusi yang meningkat bagi penerimaan negara. Pajak telah berperan strategis bagi keuangan negara (APBN) setiap tahun, yang peranannya sekitar $70 \%$ hinga $75 \%$.

Sejak tahun 2002 Ditjen Pajak melakukan modernisasi administrasi perpajakan. Langkah ini sebagai upaya menetapkan good governance dan pelayanan prima dalam pengelolaan pajak. Untuk implementasinya, maka sebagai pilot project dibentuk Kantor Pelayanan Pajak Wajib Pajak Besar (Large Taxpayers Office, LTO). Pelayanan diberikan kepada Wajib Pajak badan dalam kategori besar pada skala nasional dengan jumlah yang terbatas.

Berjalannya konsep modernisasi dan pelayanan perpajakan yang dilaksanakan oleh Wajib Pajak Besar, maka dilanjutkan pembentukan KPP Madya (Medium Taxpayers Office, MTO). Wajib Pajak yang dilayani adalah Wajib Pajak badan dalam kategori besar dalam skala regional (Kantor Wilayah) dan jumlahnya terbatas. KPP Madya ini hanya ada satu di setiap Kanwil DJP (walaupun belum semuanya). Selanjutnya, dibentuk KPP Pratama (Small Taxpayers Office, STO), yakni KPP yang selama ini telah ada dan dikembangkan, dengan menerapkan prinsip modernisasi administrasi perpajakan. WP yang dilayani adalah di luar yang telah terdaftar di KPP WP Besar dan KPP Madya.

Ketentuan, prosedur, dan aktifitas perpajakan juga terus diarahkan untuk peningkatan pelayanan agar menjadi business friendly bagi masyarakat terutama bagi para pelaku bisnis. Dengan demikian, pandangan masyara-kat terhadap pajak yang selama ini dianggap sebagai

12 Fidel, 2008, Pajak Penghasilan (Pembahasan UU No. 36/2008 tentang Pajak Penghasilan dengan Komentar Pasal Per Pasal), Jakarta: Carofin Publishing, hlm. 30. momok bahkan dianggap sebagai beban kuantitatif, diharapkan dapat berubah. Masyarakat memandang pajak menjadi sesuatu kewajiban partisipatif warga tanpa terkecuali (kualitatif) kepada negara.

Sistem Perpajakan khususnya yang berkaitan dengan Korporasi di Indonesia perlu menyesuaikan ke paradigma business friendly, dengan karakteristik sebagai berikut. Pertama, sesuai dengan asas-asas perpajakan yang berlaku secara internasional; kedua, memberikan perlindungan terhadap hak-hak masyarakat pembayar pajak (tax payer's rights) disamping mengatur kewajibannya (prinsip kesetaraan/ equality); ketiga, memiliki ketentuan-ketentuan yang jelas, transparan dan mengandung kepastian hukum agar tidak diinterpretasikan secara berbeda-beda oleh pelaksana di lapangan; keempat, mendorong pelaksanaan good governance dan menghindari praktek kolusi, korupsi, dan nepotisme; kelima, menerapkan sistem self assessment secara konsisten; keenam, memiliki basis pembayar pajak (tax ba-se) yang luas; dan ketujuh, mengenakan tarif pajak yang kompetitif..$^{13}$

Perubahan paradigma pengelolaan itu sangat penting dan konstruktif untuk memenuhi tuntutan berbagai pihak sebagai pemangku kepentingan (stakeholders) terhadap perpajakan. Selain itu, modernisasi perpajakan yang dilakukan juga dalam kerangka melaksanakan good governance, clean governance, dan pelayanan prima kepada masyarakat. Dengan demikian optimalisasi pemungutan pajak dapat terlaksana dengan baik, efektif dan efisien. Perubahan paradigma perpajakan dapat dirumuskan dalam tabel 3 di bawah ini.

Tabel 3: Perubahan Paradigma Perpajakan

\begin{tabular}{|l|l|}
\hline \multicolumn{1}{|c|}{ PARADIGMA LAMA } & \multicolumn{1}{|c|}{ PARADIGMA BARU } \\
\hline $\begin{array}{l}\text { Pajak sebagai beban } \\
\text { kuantitatif }\end{array}$ & $\begin{array}{l}\text { Pajak sebagai } \\
\text { kewajiban partisipatif } \\
\text { (kualitatif) }\end{array}$ \\
\hline $\begin{array}{l}\text { Kurang bersahabat } \\
\text { dengan korporasi }\end{array}$ & $\begin{array}{l}\text { Lebih bersahabat } \\
\text { dengan korporasi } \\
\text { (business friendly) }\end{array}$ \\
\hline Fiskus sebagai & Fiskus sebagai \\
\hline
\end{tabular}

13 Loc.cit. 


\begin{tabular}{|l|l|}
\hline “Penguasa" & “Pelayan" \\
\hline $\begin{array}{l}\text { Lebih menekankan } \\
\text { fungsi budgeter }\end{array}$ & $\begin{array}{l}\text { Keseimbangan antara } \\
\text { fungsi budgeter dan } \\
\text { regulerend }\end{array}$ \\
\hline $\begin{array}{l}\text { Kedudukan Fiskus dan } \\
\text { WP tidak setara } \\
\text { (superioritas negara vs } \\
\text { inferioritas rakyat) }\end{array}$ & $\begin{array}{l}\text { Kedudukan Fiskus dan } \\
\text { WP setara (equal) }\end{array}$ \\
\hline $\begin{array}{l}\text { Kurang berorientasi } \\
\text { pada pemenuhan hak- } \\
\text { hak tax payer (pajak } \\
\text { sebagai kewajiban } \\
\text { kenegaraan) }\end{array}$ & $\begin{array}{l}\text { Lebih berorientasi pada } \\
\text { kewajibangan hak dan }\end{array}$ \\
\hline $\begin{array}{l}\text { Filosofi pajak } \\
\text { terlepas/kering dari } \\
\text { spirit moral-spiritual }\end{array}$ & $\begin{array}{l}\text { Filosofi pajak diberi ruh } \\
\text { dengan paradigma } \\
\text { moral-spiritual }\end{array}$ \\
\hline
\end{tabular}

Hukum pajak yang progresif dengan menggunakan paradigma baru diharapkan akan menampilkan sosok perpajakan yang lebih adil dan humanis, sehingga dapat mendorong kesadaran munculnya kepatuhan sukarela dari WP yang diikuti dengan tingginya transparansi dan tanggung jawab fiskus (negara) untuk me-wujudkan kesejahteraan rakyat. Pembaharuan tata hukum diartikan sebagai menyusun suatu hukum untuk menyesuaikan dengan perubahan masyarakat. ${ }^{14}$ Pembaharuan hukum ini dilakukan melalui pembangunan sistem. Pembangunan hukum diletakkan atas dasar adanya politik hukum yang jelas tujuan dan sasarannya. ${ }^{15}$

Pajak merupakan fenomena umum sebagai sumber penerimaan negara yang berlaku di berbagai negara. Dari hasil penelitian menunjukkan bahwa hampir semua negara di dunia mengenakan pajak kepada warganya, kecuali beberapa negara yang kaya sumber daya alam yang dijadikan sebagai sumber utama penerimaan negara, tidak mengenakan pajak. Tiap negara membuat aturan dan ketentuan dalam menggerakkan dan memungut pajak di negaranya, yang umumnya mengikuti prinsip-prinsip atau kaidah dalam perpajakan. Misalnya, aspek

14 Lihat Hasnati, Pertautan Kekuasaan Politik dan Negara Hukum, Jurnal Hukum Respublica Fakultas Hukum Vol. 3 No. 1 Tahun 2003, Universitas Lancang Kuning Pekanbaru, hlm. 102-113.

15 Saut P. Panjaitan, "Politik Pembangunan Hukum di Bidang Investasi Suatu Keniscayaan Konstitusi Ekonomi", Jurnal Konstitusi Vol. 7 No. 2 April 2010, Mahkamah Konstitusi Republik Indonesia, hlm. 49. keadilan dalam pengenaannya, adanya rasa nyaman bagi pembayar pajak, besaran atau jumlah pajak yang proporsional (efisien), efektif dan mudah dalam pemungutannya secara administrasi dan mekanisme perpajakan, dan lain sebagainya.

Peranan pajak bagi tiap negara pada dasarnya berbeda antara satu negara dengan negara lainnya. Apalagi bila berbeda sistem, kemajuan perekonomian, politik, dan pemerintahan dari negara yang menerapkan. Hal ini terlihat diantaranya dari persentase besaran pajak terhadap Produk Nasional Bruto (PNB) dalam satu kurun waktu tertentu.

\section{Penutup \\ Simpulan}

Undang-undang No. 30 Tahun 2008 tentang Pajak Penghasilan (PPh) mengatur perubahan tarif pajak bagi WP Badan dan Bentuk Usaha Tetap (BUT). Di dalam UU No. 36 Tahun 2008 Pasal 17 ayat 1 (b), tarif bagi WP Badan dan BUT ditetapkan sebagai tarif tunggal (flat rate) yaitu sebesar 28\%. Tarif ini mulai tahun 2010 diturunkan lagi menjadi 25\%. Perubahan dari semula tarif progresif menjadi tarif tunggal boleh jadi merupakan jawaban atas banyak usulan dari para pelaku usaha agar tarif pajak di Indonesia lebih sederhana dan dapat mendorong dunia usaha (korporasi) untuk lebih kompetitif.

Berdasarkan analisis komparatif ternyata kebijakan penetapan tarif pajak penghasilan yang baru justru memberatkan sebagian besar WP perusahaan, dan hanya sedikit memberikan keuntungan bagi WP perusahaan khususnya yang memiliki Penghasilan Kena Pajak (PKP) besar. Dengan kata lain, tarif pajak yang baru mengakibatkan terjadinya ketidak-adilan dalam penetapan beban pajak penghasilan badan.

Terdapat benturan antara asas kesederhanaan pemungutan pajak (simplicity) dengan asas keadilan (justice). Tuntutan akan sistem pemungutan pajak penghasilan badan yang sederhana, misalnya dengan menggunakan tarif tunggal, ternyata berbenturan dengan realitas adanya jumlah penghasilan yang tidak sama, hal mana akan lebih memberikan rasa keadilan apabila menggunakan tarif progresif dengan 
menggunakan lapisan tarif. Aparatur perpajakan dalam setting peraturan perundang-undangan perpajakan Indonesia diberikan otoritas (kewenangan) yang sangat besar sehingga melahirkan konstruksi keterhubungan yang sub-ordinatif.

Hukum pajak progresif dengan menggunakan paradigma baru (change of tax paradigm) diharapkan akan menampilkan sosok perpajakan yang lebih adil dan humanis, sehingga dapat mendorong munculnya kepatuhan sukarela dari WP yang diikuti dengan tingginya transparansi dan tanggung jawab fiskus (negara) untuk mewujudkan kesejahteraan rakyat.

\section{Daftar Pustaka}

Asnawi, Eddy. "Relevansi Politik Hukum dan Strategi Pembangunan Hukum dalam Rangka Menuju Sistem Hukum Nasional”. Jurnal Respublica Vol. 3 No. 1. Tahun 2003. Pekanbaru: Universitas Lancang Kuning;

Budiyono, Tri. "Pemusatan Otoritas Aparatur Perpajakan dan Kejahatan Pajak". Jurnal Hu-kum Vol. 15 No. 3. Desember 2003. Semarang: FH Unissula;

Fidel. 2008. Pajak Penghasilan (Pembahasan UU No. 36/2008 tentang Pajak Penghasilan dengan Komentar Pasal Per Pasal). Jakarta: Carofin Publishing;

Hartono, Sunaryati. "Politik Hukum Bhineka Tunggal lka Dalam Pembangunan Hukum Nasional". Majalah Hukum Nasional Vol. 8 No. 2. Tahun 2008. BPHN;

Hasnati. "Pertautan Kekuasaan Politik dan Negara Hukum" Jurnal Hukum Respublica Fakultas Hukum No. 1. Tahun 2003. Pekanbaru: Universitas Lancang Kuning;

Nordin. "Pajak Daerah Sebagai Sumber Pendapatan Daerah/Kota Di Era Otonomi
Daerah”. Jurnal Delegasi. 2 Agustus 2005. Banjarmasin: STIA Banjarmasin;

Nugroho, Andrinato Dwi. "Anti Avoidance Rules di Indonesia Pasca amandemen UU Pajak Penghasilan". Jurnal Mimbar Hukum Vol. 21 No. 1. Februari 2009. Yogyakarta: FH UGM;

Panjaitan, Saut P. “Politik Pembangunan Hukum di Bidang Investasi Suatu Keniscayaan Konstitusi Ekonomi". Jurnal Konstitusi Vol. 7 No. 2. April 2010. Jakarta: Mahkamah Konstitusi Republik Indonesia;

Ratna, Hernalia. "Implementasi Politik Hukum Dalam Amandemen UUD 1945 Terhadap Pembangunan Hukum Sistem Hukum Nasional". Jurnal Perspektif Hukum Vol.6 No. 2. November 2006. Surabaya: Universitas Hang Tuah;

Reuven Avi-Yonah, 2004, Corporations, Society, and The State: A Defence of The Corporate Tax, University Of Michigan: John M. Olin Center For Law and Economics;

Riyanto, Astim. "Pancasila Dasar Negara Indonesia". Jurnal Hukum dan Pembangunan Vol. 37 No. 3. Juli-September 2007. Jakarta: $\mathrm{FH} \mathrm{UI}$;

Sunarko, Edi. "Kebijakan Perpajakan Pemerintah Republik Indonesia Terhadap Kegiatan Investasi Dalam Kerangka Asean Free Trade Area (AFTA)". Jurnal Hukum dan Dinamika Masyarakat. Oktober 2004. Semarang: FH Untag Semarang;

Uno, Sandiaga S. 2010. dalam Seminar Bisnis tentang "Insentif Pajak dalam Mendorong Dunia Bisnis", diselenggarakan oleh Kanwil Pajak Jateng II dan Tax Center USB, Solo, 7 Juli;

Wijoyo, Hadion. "Peranan Hukum Pajak Dalam Pembangunan Ekonomi". Jurnal Hukum Respublica. Vol. 4 No. 2 Tahun 2005. Pekanbaru: Universitas Lancang Kuning. 